\title{
Implementation of Good Environmental Governance in the Management of Forest Resources in Banten Province, Indonesia in terms of Environmental Law
}

\author{
Imam Haryanto; Dwi Desi Yayi Tarina \\ Faculty of Law, Universitas Pembangunan Nasional Veteran Jakarta, Indonesia \\ http://dx.doi.org/10.18415/ijmmu.v7i7.1782
}

\begin{abstract}
Forests are an integral and inseparable part of the lives of the people who live around them. The potential of natural resources in Indonesia are plentiful, it has a severe impact and high damage. The deteriorating condition of forests, among others are also not balanced with the ability to create plantations and adequate in accordance with the needs of industrial markets. Of the total area of Banten Province amounting to 966,292 Ha, the Area of Forest Area in Banten Province in 2017 according to the Decree of Partial Determination of Forest Areas is an area of 195,286.09 Ha. The purpose of this research is to provide a solution to the Banten Provincial Environment Agency regarding its role in overseeing and controlling the management of forest product resources to implement good environmental governance. The method used in this research is an empirical normative juridical approach, which is an approach that focuses on norms or norms, so that the problem will be assessed and analyzed by referring to the applicable laws and regulations relating to the problem of managing forest resources.
\end{abstract}

Keywords: Management; Resources; Good Environmental Governance

\section{Introduction}

Interaction between rural communities and the environment surrounding forest has been going on for centuries in the frame of cross-generation cosmic balance. Management and utilization of forest resources in each forest village community has its own characteristics (local specific) in accordance with the cultural characteristics of the people who live in and around the forest. Forest resources is defined as a natural resource that has economic value, religious, political, social and cultural. Therefore, the survival of the people and forests is very dependent on the availability of forest resources that are around the environment (Nugraha, 2005). Forests in Indonesia are wet tropical forests due to geography, hydrographic factors and have various types of climate and great potential for development. Therefore, forests must be managed and utilized with noble character in the framework of the embodiment of gratitude.

The potential of natural resources in Indonesia are plentiful, it has a severe impact and high damage. The deteriorating condition of forests, among others are also not balanced with the ability to create plantations and adequate in accordance with the needs of industrial markets. The main cause is 
political felling without permission (illegal logging). Forest is one of the natural resources potential to be utilized for national development with the aim to provide maximum benefits for the people of Indonesia and to the good management of natural resources such as forests. However, the utilization many face threats, challenges, obstacles and disturbances to forest conservation.

In line with Article 33 paragraph 3 of the 1945 Constitution as a constitutional basis it is explained that "The earth, water and natural resources contained therein are controlled by the state and are used to the greatest extent possible for the prosperity of the people."

The success of the forestry sector in supporting economic growth turned out to have an impact on environmental degradation, indicated by the increasing destruction of forests or deforestation has occurred. According to the FAO report each year an average of 1,871 million hectares were destroyed or $2 \%$ of the remaining forest area in 2005, which was 88.495 million hectares. Indonesia is considered as the country with the lowest deforestation rate in the world. This level of damage has placed Indonesia in unsustainable management.

Forest according to Law Number 41 of 1999 concerning Forestry is an ecosystem unit in the form of a stretch of land containing biological natural resources dominated by trees in their natural environment which cannot be separated from one another. A collection of trees is considered a forest if it is able to create climate and local environmental conditions that are different from those outside it. If we were in a tropical rain forest, it was like entering into a steam room warm and humid, which is different than the surrounding farming areas. The view is different. This means that all the other plants and animals (up to smallest), as well as various other inanimate elements including parts of an integral constituent of the forest.

Forest as an ecosystem not only save natural resources such as timber, but still a lot of potential non-timber that can be taken by society through the cultivation of agricultural crops on forest land. As a function of the forest ecosystem, it plays a very important role in various things such as water supply, oxygen-producing, living places for millions of flora and fauna, the role of balancing the environment, and preventing global warming. Besides that, it is also a function of providing water for forest life as one of the most important areas, this is because the forest is a place where various plants grow.

Of the total area of 966.292 ha of Banten province, Area Forest Area in Banten Province in 2017 according to SK Stipulation of Partial Forest Zone is an area of 195,286.09 hectares, which include (Dinas Lingkungan Hidup \& Kehutanan, 2017):
a. Conservation Forest covering an area of 100,590.56 Ha;
b. Protected forest area of 10,396.78 hectares;
c. Limited production forest area of 39,594.09 hectares;
d. Permanent Production Forest of 44,704.72 Ha.

Forest area covering 195,286.09 Ha covers $20.21 \%$ of the total area of Banten Province. The potential of timber and non-timber in Banten Province are mostly found in the state forest areas, especially the production forests and protected areas managed by Perum Perhutani Unit III West JavaBanten. Timber and non-timber production are economically cultivated in the production area. Apart from state forests, the potential for timber and non-timber in Banten Province is also found in community forests. The indicative area of community forests in Banten Province reaches 136,190.91 Ha. The largest area of community forest in Banten Province is in Lebak Regency followed by Pandeglang Regency.

The great potential of forests in Banten Province, which is almost a quarter of the total area of Banten Province, if managed properly will be used as an alternative to support the achievement of food, 
water and renewable energy sovereignty in Banten Province. In addition, the Collaborative Forest Management System also opens opportunities for forest village communities to be actively involved in forest management. Therefore, the Banten Provincial Government hopes that the supporting institutions for empowering forest village communities who play a direct role in forest management, can work optimally and carry out their duties by following the local wisdom values that still exist and are inherent in the community so that there is a balance in managing natural resources of forest products.

Excessive use of natural resources will damage the environment. Environmental Governance is an interaction with the environment that is managed conceptually. Namely on the need to understand and manage the reciprocal relationships between social systems and ecosystems, more than that social system management needs to be maintained by promoting ecological values and vice versa ecosystem resilience can be maintained through the management of social systems that are guided by ecological rules. In the principle of good governance, not only the government but also citizens, the community, especially the business / private sector, and community organizations. This is because the change in the development paradigm by reviewing the role of government in development, which initially acted as a regulator and market participant, became how to create a conducive climate and investigate infrastructure that supports the business world (Harmiati, 2018).

Natural resource management is an important issue in the implementation of decentralization and regional autonomy, because it is this sector that often triggers a sense of injustice felt by the region in the era of centralized government. The forestry sector is one of the sectors in the management of natural resources which in the new order was very centralized in its implementation. The management of forest resources is carried out in an exploitative and centralized manner without paying attention to the regions, and results in the marginalization of the local community. The people who live in and around the forest are neglected and cannot enjoy the results that they deserve, and that is also not proportional to the perceived impact of the forest management (Siswoko).

\section{Literature Review}

Good Governance is generally defined as good governance. The word "good" here means to follow certain rules in accordance with the basic principles of good governance. The main key to understanding good governance is understanding of the principles in it. Starting from this principle, a measurement of government performance is obtained. This idea of good governance was first developed by international funding agencies such as the World Bank, United Nations Development Program (UNDP), and International Monetary Finance (IMF) in order to maintain and guarantee the sustainability of aid funds provided to aid target countries, aid funders see that any assistance for world countries, especially developing countries, is difficult to succeed without good governance. In the last decade, the terms governance and good governance have been developed relating to the implementation of governance in a country. In general, governance is the process of decision making and the process of how a decision is implemented at various levels of government.

According to UNDP, the definition of good governance is a synergistic and constructive relationship between the state, the private sector and the community, in principle; participation, rule of law, transparency, responsiveness, building consensus, equality, effective and efficient, responsible and strategic vision. Good governance is defined as the practice of exercising authority over the implementation of the management of various state affairs politically, economically and administratively at all levels.

If related to governance, good governance is an idea and value to regulate the pattern of relationships between the government, the private business world, and the community so that a clean, 
democratic and effective government is organized in accordance with the ideals of a prosperous, prosperous society and independent.

Any company or business entity shall ensure that the principles of good governance are applied in every aspect of business and in all ranks. The National Committee on Governance Policy (KNKG) explained the principles of good governance namely transparency, accountability, responsiveness, independence and equality and fairness needed to achieve sustainable performance while still paying attention to stakeholders.

Regarding good environmental governance, defining the environment is the sum of all the objects and conditions that exist in the space we occupy that affect our lives. While Michael suggests the environment is the physical, chemical, and biotic, surrounding and organism condition (physical, chemical and biotic conditions surrounding and organism).

Based on Article 1 paragraph (1) of Law Number 5 of 1967 concerning Provisions for Basic Forestry Provisions, which have been updated with Law Number 41 of 1999 concerning Forest Protection. The so-called forest is a field of growth of trees which as a whole is a union of living natural life and the natural environment. Forests as part of a national natural resource that has a meaning and an important role in various aspects of social life, development and the environment. Forests have a variety of benefits for life both direct benefits are felt as well as indirect benefits, the benefits of the forest are obtained if the existence of the forest is guaranteed so that it can function optimally.

Based on the enactment of Law Number 5 of 1967 concerning Provisions on Basic Forestry Provisions which have been updated with Law Number 41 of 1999 concerning Protection of Forests and Forest Areas. Forest Development aims to achieve maximum benefits as well as versatile and sustainable, both directly and indirectly in efforts to build a just and prosperous Indonesian society based on Pancasila. Therefore, aspects of forest development are a unified whole between juridical aspects, technical aspects, management aspects and administrative aspects.

Meanwhile, according to its function, forests can be divided into 4 (four) based on Article 3 of Law Number 5 of 1967, namely:

a. Protected forest; is a forest area based on the condition and physical nature of the area, there needs to be guidance to be maintained.

b. Production forest; is a forest area that is maintained as a forest area and functions to obtain forest products for the benefit of public consumption, industry and exports.

c. Forest nature reserve; is a forest area based on the condition and physical nature of the area, it needs to be fostered and maintained a diversity of plant and animal species.

d. Forest tours; is a forest area because the condition and nature of the area need to be fostered and maintained as a forest for the development of education, tourism recreation and hunting.

The meaning of the forest itself is as a very important part of the ecosystem in environmental management, making forest conservation efforts as an area that is included in the general task of development. For this reason, it is necessary to develop the environment in enlarging natural resources so that it can be used continuously by generation after generation as well as preventing deterioration in quality and improving the quality of the environment so that it is of higher quality and guides people from the position of environmental destruction to become environmental coaches.

The Government makes a general plan regarding the designation, supply, procurement and use of versatile and sustainable forests throughout the territory of the Republic of Indonesia for the benefit of: 
a. Water regulation, flood and erosion prevention and maintenance of soil disturbance.

b. The production of forest products and their marketing are used to meet the interests of the community in general and in particular for the purposes of industrial development and export.

c. The main source of livelihood is diverse for people in and around the forest.

d. Protection of the biological and natural environment for the benefit of science, national defense, recreation and tourism.

e. Transmigration, agriculture, plantation and animal husbandry.

To obtain maximum benefits from sustainable forest designated certain areas as forest land with sufficient area and the exact location.

\section{Research Methodology}

Research Object

The object of this research is forest product resources in Banten Province.

\section{Literature Research}

Literature research aims to study, examine and trace secondary data in the form of primary, secondary and tertiary legal materials.

a. Primary law materials include:

1) The 1945 Constitution of the Republic of Indonesia.

2) Act No. 5 of 1960 on Basic Regulation of Agrarian.

3) Act No. 5 of 1999 on Conservation of Natural Resources and Ecosystems.

4) Act No. 24 of 1992 on Spatial Planning.

5) Act No. 23 of 1997 on Environmental Management.

6) Act No. 22 of 1999 on Regional Government.

7) Act No. 41 of 1999 on Forestry.

b. Secondary Legal Materials include:

Books, journals, dissertations, research reports, and papers.

\section{Data Analysis}

Drawing conclusions from the results of research that has been collected is done using qualitative juridical analysis methods, juridical because research departs from existing legislation as positive law. Qualitative, namely analyzing data that is based on efforts to find principles and information or other information obtained from library studies to find out its relation to the main problem.

\section{Approach Method}

Using the method of empirical normative juridical approach, which is an approach that focuses on aspects of norms or rules, so that the problem will be assessed and analyzed by referring to applicable legislation and relating to the problem of managing forest product resources. 


\section{Discussion}

Environmental control and management is closely related to the welfare of the people of a country. It is through environmental control and management (where natural resources are in it) that people's welfare is to be realized. For countries that claim to be the welfare state (welfare state), making the welfare of the people as a living destination country or state. All activities of state administration are oriented towards efforts to achieve and fulfill the welfare of the people.

Based on the preamble of the Constitution of the Republic of Indonesia Year 1945 explicitly stated that one purpose of the state and the formation of the state government is to promote the general welfare. To achieve this general welfare, the 1945 Constitution gives the state exclusive rights to control the environment and natural resources, which in legal literature is known as the right to control the state. The integration of the environment and natural resources, the right to control the state and the welfare of the people as stipulated in Article 33 paragraph 3 of the 1945 Constitution which states that "The earth, water and natural resources contained therein are controlled by the state and used as much as possible for the welfare of the people".

Based on the state's right to control, the state of Indonesia has established various policies and regulations as a guidance and legal baseline in managing the environment and natural resources in order to realize people's welfare. In reality, environmental management in Indonesia still faces the same problem, namely the clash between various laws and regulations, especially between sectoral laws related to natural resources (which are more oriented to the utilization of economic resources and environmental laws (which are considered to overemphasize aspects of life protection). As a result, environmental management and control under government control through statutory provisions as umbrella provisions has not been able to achieve the goals of environmental management, the realization of environmental functions and the achievement of people's welfare.

To ensure legal certainty so that people have the awareness to participate in preserving their environment, the government has prepared legal instruments especially environmental law to ensnare pollutants and environmental destroyers. Act in question is Act No. 4 of 1982 regarding the Environment (UULH) and Law No. 23 of 1997 on Environmental Management (UUPLH) and has been refined by Act newest namely Law No. 322009 on the Protection and Environmental Management (UUPPLH). The existence of this law is expected to be a reference for law enforcement officials to act against those who have intentionally or unintentionally polluted the environment. Law enforcers can solve cases of environmental crimes that occur, especially the problem of water pollution by industrial waste that often occurs especially in big cities.

Good Environmental Governance practices in recent years in Indonesia have been in the public spotlight. Environmental damage and declining environmental quality are often linked and it is often stated that the cause is the existence of an Environmental Governace that is not in accordance with the proper laws and regulations. This condition is a result of the implementation of corporate governance that does not meet the management standards of an institution or company.

According to David Keirsey, legal politics is the policy of the state to implement the law (Kairsy, 1990). E. Utrecht explained that the politics of law is a normative science that is the science that determines the things that should exist (Desmon, 2013). Something that should exist in a normative form is the laws and regulations, both material and formal. Legal politics then has a role to determine the means and objectives to be achieved in the manufacture or implementation of a legal product. In line with this Satijpto Rahardjo argues, in legal politics, legal development must have a double meaning. First, as an effort to renew the positive law itself, so that it is in accordance with the need to serve the community at the latest level of development. Second, as an effort to make law functional during the development 
period, namely by taking part in making social changes as needed by the developing community (Rahardjo, 2009).

Moh. Mahfud MD stated that legal politics is a legal policy that will or has been implemented nationally by the Government of Indonesia. This legal policy consists of, first, the development of law with the core of making and updating legal materials so that they can meet their needs. Second, the implementation of existing legal provisions including the affirmation of the functions of the institution and the development of law enforcers (MD, 1998). Based on this understanding, according to Moh. Mahfud is seen as legal politics including the process of making and implementing laws that can show the nature and direction in which the law is built and enforced. Based on the understanding of the concept of legal politics above, in this study legal politics is intended as a legal policy which is the basis of environmental management in Indonesia. Talking about legal policy, of course the 1945 Constitution as the basic norm becomes the first reference, including in the management of the environment and natural resources.

Based on Law No. 23 of 2000 total area of Banten province is $8651.20 \mathrm{~km}$. At the end of 2016, according to Minister Regulation No. 6 of 2008 total area of Banten province administration is 9662.92 $\mathrm{km}$, which consists of 8 (eight) regency / city with a land area of each district / city, namely:
a. Pandeglang Regency $(2,746.89 \mathrm{~km})$
b. Lebak Regency $(3,426.56 \mathrm{~km})$
c. Tangerang Regency $(1,011.86 \mathrm{~km}$
d. Serang Regency $(1,734.28 \mathrm{~km})$
e. Tangerang City $(153.93 \mathrm{~km})$
f. City of Cilegon $(175.50 \mathrm{~km})$
g. City of Serang $(266.71 \mathrm{~km})$
h. South Tangerang City $(147.19 \mathrm{~km})$.

The area of Banten reaches 9,663 $\mathrm{km}$ or around 0.51 percent of the total land area of Indonesia. Means, Banten is a province with the fifth smallest area in Indonesia after the Riau islands ( 0.43 percent $)$, Bali (0.30 percent), DI Yogyakarta (0.16 percent) and DKI Jakarta (0.03 percent).

Geographically Banten Province is located between 105 degrees 01'11 "to 106 degrees 09'12" East Longitude, and 05 degrees 07'50 "to 07 degrees 01 '01". The boundaries of the banten area, the north bordering the Java Sea, the east with DKI Jakarta Province and West Java Province, the south with the Indian Ocean and the west with the Sunda Strait.

The topography of the Banten Province region ranges from 0-1000 meters above sea level. In general, the topographic condition of the Banten Province region is lowlands ranging from 0-200 meters above sea level, located in the City of Cilegon, Tangerang City, Pandeglang Regency and most of Serang Regency. The Central Lebak area and a small portion of Pandeglang Regency have elevations ranging from 201-2000 meters above sea level and the East Lebak area has an altitude of 501-2000 meters above sea level located on the peaks of Mount Sanggabuana and Mount Halimun.

The climate of the Banten region is influenced by Monsoon angina and La Nina waves. The weather is dominated by West Winds from the Indian Ocean and Asian Winds in the rainy season and East Winds in the dry season. The temperature in Banten in 2016 averaged 27.70c, with 84\% humidity. The rain falls every month, with the number of days and rainfall in each year totaling 238 days and 2,419 $\mathrm{mm}$. 
Of the total area of Banten Province amounting to 966,292 Ha, the area of forest area in Banten Province in 2017 in accordance with the Decree on Partial Determination of Forest Areas is 195,286.09 ha, which includes:

a. Conservation Forest covering an area of 100,590.56 Ha

b. Protected forest area of $10.396 .78 \mathrm{Ha}$

c. Limited Production Forest covering an area of 39,593.09 Ha

d. Permanent Production Forest of 44,704.72 Ha.

Forest area of 195,286.09 hectares covering at 20,21\% of the total area of the province of Banten.

Timber and non-timber potential in Banten Province is mostly found in state forest areas, especially production forests and protected forests managed by Perum Perhutani Unit III West JavaBanten. Timber and non-timber production are economically cultivated in production forest areas. The production forest area in Banten Province which is managed by Perum Perhutani Unit III West Java Banten covers an area of 78,487.64 Ha. The area of the production forest is divided into 6 (six) company classes, namely teak, mahogany, mangium, resin, meranti, and brackish. Apart from state forests, the potential for timber and non-timber in Banten Province is also found in the people's forests. The indicative area of community forests in Banten Province in 2016 reached 136,190.91 Ha. The largest area of community forest in Banten Province is in Lebak Regency followed by Pandeglang Regency. The dominant community forest plants in Banten Province are sengon, durian, tangkil, teak and mahogany.

Production of forest products is the entire production of forest products both wood and non-wood in the province of Banten originating from the people's production forest (state forest) area. The state forest area (production and protection) is under the management of the Forestry BUMN namely Perum Perhutani Unit III West Java-Banten, while the production of logs from community forests is managed independently by the people of Banten Province. Production of carpentry wood from state forests in Banten Province is dominated by mangrove, teak and mahogany acacia wood.

The superior potential of Banten Province is environmental services, in the form of:

a. Water supply services;

Most of the conservation areas in Banten Province produce environmental services in the form of water, one of which is Ujung Kulon National Park. The rivers that have springs from within the Ujung Kulon National Park are 23 (twenty three) rivers spread over 2 (two) districts and 11 (eleven) villages.

b. Biodiversity service provider;

Conservation areas in Banten Province have high biodiversity potential that can be utilized sustainably. Various medicinal plants and fauna can be utilized through various cultivation or breeding techniques.

c. Landscape / ecotourism beauty provider services;

Almost all conservation areas in Banten Province have the potential of landscape beauty. This can be used by managers to encourage ecotourism. The varied types of ecosystems are one of the interesting tourist attractions that can be offered. The beauty of the underwater world on Peucang Island and Panaitan Island, the naturalness of lowland tropical rain forests, wild life in grazing areas, bird habitat, and white sand beaches are an attraction for tourists.

The establishment of the Environment and Forestry Service of the Banten Province is based on the Banten Province Regional Regulation No. 8 of 2016 concerning the Establishment and Composition of the Banten Province Regional Apparatus. Furthermore, the description of the tasks, functions and organizational structure is determined based on the Banten Governor Regulation No. 83 of 2016 
concerning the Position, Main Tasks, Functions, Types, Organizational Structure and Work Procedures of the Banten Provincial Region.

The Office of Environment and Forestry is an element of implementing regional government affairs which is domiciled and is responsible to the Governor through the Regional Secretary. The Department of Environment and Forestry has the task of assisting the governor in carrying out government affairs in the field of Environment and Forestry and the Assistance Task assigned to the Provincial Region.

The vision of the Department of Environment and Forestry of Banten Province is the realization of environmental quality and forest sustainability for sustainable development. From this vision 3 (three) elements can be drawn, namely:

a. Quality environment; the quality of the environment is reflected by the condition of the environment being at the tolerance needed for human life and residing resources about a safe population, able to increase the ability of natural resources to contribute to the national economy.

b. Sustainable forest; forest sustainability is indicated by the preservation of the extent and function of forests to sustain life, provide forests for social, economic activities of the people and preserve biodiversity.

c. Sustainable development; is an effort made to carry out development that takes into account the balance between the sustainability of economic, ecological and socio-cultural functions in the management of forest resources to improve the quality of human life in the future.

The establishment of the Department of Environment and Forestry has the aim of improving the quality of performance in planning, controlling, evaluating development, data and research and development in accordance with the formulation of strategies and policy directions, program priorities and activities in a measurable, clear and targeted manner. It also aims to maintain environmental quality, control pollution, biodiversity, control climate change, maintain the extent and function of forests, provide forests for the social and economic community and maintain the balance of the ecosystem.

The Office of the Environment and Forestry in carrying out its duties carries out functions and authorities;

a. Plan for the protection and management of the environment (RPPLH) provinces and the Strategic Environmental Assessment (SEA) for policy, plans and / or Program (KRP) province;

b. Prevention, control and recovery of pollution and / or environmental damage across regency / city Region in 1 (one) Provincial Region;

c. Provincial Health Management;

d. B3 waste collection across regency / city Region in 1 (one) Provincial Region;

e. Guidance and supervision of businesses and / or activities for which environmental permits and PPLH permits are issued by the provincial government;

f. Determination of recognition of indigenous peoples (MHA), local wisdom or traditional knowledge and rights of local wisdom or traditional knowledge and rights of indigenous and tribal peoples related to PPLH in two or more regency / city regions in 1 (one) provincial Region;

g. Increasing the capacity of indigenous and tribal peoples, local wisdom or traditional knowledge and local wisdom or traditional knowledge and rights of indigenous and tribal peoples related to PPLH in two or more regency / city regions in 1 (one) provincial Region;

h. Providing education, training and environmental counseling for social institutions at the provincial level; 
i. Providing environmental awards at the provincial level;

j. Settlement of public complaints in the field of PPLH towards:

1) Issuance of business and / or activity recommendations for which environmental permits and / or PPLH permits are issued by the provincial government;

2) Business coaching and / or activities that the location and / or traffic impacts of districts / cities;

k. Handling of waste in the landfill / regional TPST;

1. Implementation of the forest management unit for forest management except for the Conservation Forest Management Unit (KPHK);

m. Implementation of forest management unit management plans except for Conservation Forest Management Units (KPHK);

n. Implementation of forest utilization in production forest areas and protected forests, including:

1) Utilization of forest areas;

2) Utilization of non-timber forest products;

3) Collection of forest products;

4) Utilization of environmental services except utilization of carbon storage and / or sequestration;

o. Implementation of rehabilitation outside the State forest area;

p. The implementation of forest protection in protected forests and production forests;

q. Implementation of processing non-timber forest products;

r. Implementation of wood forest product processing with a production capacity of $<6000 \mathrm{~m}^{3}$ / year;

s. Implementation of the management of Forest Areas with Specific Purposes (KHDTK) for religious purposes;

t. Implementation of protection, preservation and sustainable use of Great Forest Parks (TAHURA) across regency / city areas;

u. Implementation of protection of wild plants and animals that are not protected and / or not included in the appendix (Appendix) of CITES.;

v. Implementation of management of important ecosystem value areas and buffer zones of nature reserves and nature conservation areas;

w. Implementation of provincial forestry counseling;

1) Community empowerment in the forestry sector;

2) Implementation of management of watersheds (DAS) across regency / city regions and in regency / city regions in 1 (one) provincial Region;

$\mathrm{x}$. The implementation of other functions given by the governor is related to their duties and functions.

The existence of the Department of Environment and Forestry in Banten Province subsequently has several policies related to the environment, including:

Thus, the program implemented by the Department of Environment and Forestry Banten many that lead to the conservation and management of forest resources in accordance with the principles of good environmental governance. In the program of activities also carried out discussions and training on forest areas, forest use to the discussion on forest product resources in the form of wood or in the form of honey produced by forest bees. 


\section{References}

Desmon, O. R. (2013). Studi Politik Hukum: Suatu Optik Politik Hukum. Yogyakarta: PT. Thafa Media.

Dinas Lingkungan Hidup \& Kehutanan. (2017). Profil Dinas Lingkungan Hidup dan Kehutanan tahun 2017. Banten: Dinas Lingkungan Hidup dan Kehutanan.

Harmiati, d. (2018). Implementasi Good Enviromental Governance dalam Pengelolaan Daerah Aliran Sungai (DAS) Bengkulu. Jurnal Ilmu Pemerintahan Kajian Ilmu Pemerintahan dan Politik Daerah, 136-148.

Kairsy, D. (1990). The Politics of Law, A Progressive Critique. New York: Pantheon Books.

MD, M. (1998). Politik Hukum di Indonesia. Jakarta: LP3ES.

Nugraha, A. (2005). Antropologi Kehutanan. Banten: Wana Aksara.

Rahardjo, S. (2009). Hukum dan Perubahan Sosial. Yogyakarta: Genta Publishing.

Siswoko, B. D. (n.d.). Good Forest Governance: Sebuah Keniscayaan dalam Pengelolaan Sumberdaya Hutan Lestari. Jurnal Ilmu Kehutanan, Universitas Gadjah Mada Yogyakarta, 1-12.

\section{Copyrights}

Copyright for this article is retained by the author(s), with first publication rights granted to the journal.

This is an open-access article distributed under the terms and conditions of the Creative Commons Attribution license (http://creativecommons.org/licenses/by/4.0/). 